\title{
Mollusks and a crustacean from early Oligocene methane-seep deposits in the Talara Basin, northern Peru
}

Steffen Kiel, Frida Hybertsen, Matúš Hyžný, and Adiël A. Klompmaker

Acta Palaeontologica Polonica 65 (1), 2020: 109-138 doi:https://doi.org/10.4202/app.00631.2019

A total of 25 species of mollusks and crustaceans are reported from Oligocene seep deposits in the Talara Basin in northern Peru. Among these, 12 are identified to the species-level, including one new genus, six new species, and three new combinations. Pseudophopsis is introduced for medium-sized, elongate-oval kalenterid bivalves with a strong hinge plate and largely reduced hinge teeth, rough surface sculpture and lacking a pallial sinus. The new species include two bivalves, three gastropods, and one decapod crustacean: the protobranch bivalve Neilo altamirano and the vesicomyid bivalve Pleurophopsis talarensis; among the gastropods, the pyropeltid Pyropelta seca, the provannid Provanna pelada, and the hokkaidoconchid Ascheria salina ; the new crustacean is the callianassid Eucalliax capsulasetaea. New combinations include the bivalves Conchocele tessaria, Lucinoma zapotalensis, and Pseudophopsis peruviana. Two species are shared with late Eocene to Oligocene seep faunas in Washington state, USA: Provanna antiqua and Colus sekiuensis; the Talara Basin fauna shares only genera, but no species with Oligocene seep fauna in other regions. Further noteworthy aspects of the molluscan fauna include the remarkable diversity of four limpet species, the oldest record of the cocculinid Coccopigya , and the youngest record of the largely seep-restricted genus Ascheria. Eucalliax is recorded for the first time from a seep and from the Oligocene.

Key words: Gastropoda, Bivalvia, Crustacea, Decapoda, biogeography, cold-seep, Paleogene, South America.

Steffen Kiel [steffen.kiel@nrm.se] and Frida Hybertsen [frida.hybertsen@nrm.se

], Department of Palaeobiology, Swedish Museum of Natural History, Box 50007, 10405 Stockholm, Sweden. Matúš Hyžný [matus.hyzny@uniba.sk ], Department of Geology and Paleontology, Faculty of Natural Sciences, Comenius University, Ilkovičova 6, 84215 Bratislava, Slovakia. Adiël A. Klompmaker [adielklompmaker@gmail.com], Department of Integrative Biology \& Museum of Paleontology, University of California, Berkeley, 1005 Valley Life Sciences Building \#3140, Berkeley, CA 94720, USA; The University of Alabama Museums \& Alabama Museum of Natural History, The University of Alabama, Box 870340, Tuscaloosa, AL 35487, USA. 
This is an open-access article distributed under the terms of the Creative Commons

Attribution License (for details please see creativecommons.org), which permits unrestricted use, distribution, and reproduction in any medium, provided the original author and source are credited.

FarF Full text $(2,537.7 \mathrm{kB})$ 